\section{Intellectual Resilience - Draft of a New Educational Approach for the Geography Classroom}

Gl_Forum 2021, Issue 2

Page: 45 - 53

Full Paper

Corresponding Author: daniel.raithofer@univie.ac.at DOI: 10.1553/giscience2021_02_s45

\author{
Daniel Raithofer and Christiane Hintermann \\ University of Vienna, Austria
}

\begin{abstract}
Major crises such as the Covid-19 pandemic put societies to the test. The conjuncture of globalization, with all its challenging transformation processes, social inequality, and the epidemic spread of a new (viral) pathogen has fuelled feelings of uncertainty and insecurity in virtually every part of society, on a global scale. Focusing on learners, this paper proposes 'intellectual resilience' as a new educational concept aiming to empower learners to more fully comprehend and navigate global crises. An intellectually resilient person is defined as someone who can use multiple scientific approaches and concepts in a participative, democratically informed way. The aim is to explore the potential of school geography education to support young learners in handling crisis situations
\end{abstract}

\title{
Keywords:
}

resilience, geography education, crises, Covid-19

\section{Introduction}

With the Covid-19-pandemic, we are currently facing the severest social and economic crisis on a global scale since the end of World War II. Even though the pandemic is first and foremost a health crisis, there can be no doubt that Covid-19 affects every part of our lives. Unlike other global challenges such as the financial meltdown in 2008, it affects everybody's wellbeing, albeit to different degrees. As the UNHCR emphasizes, more vulnerable groups in society, such as 'people living in poverty situations, older persons, persons with disabilities, youth, and indigenous peoples' (UN, 2020), are hit harder. Everybody has to cope with the effects of Covid-19, although not everyone has the same possibilities and abilities to do so. In what follows, we will outline a new educational concept aiming to foster learners' intellectual resilience. ${ }^{1}$ The intention of this approach is to empower learners to more fully comprehend, negotiate and shape today's 'super-complex' crises (Barnett, 2000). The concept will be elaborated from the perspective of the geography classroom and uses the current Covid-19

\footnotetext{
${ }^{1}$ The conceptualization and implementation of the approach will be undertaken within the context of a PhD project.
} 
situation as an example of a global crisis that increases feelings of uncertainty in wide parts of society.

However, before Covid-19, other risks had spread from their geographic sources and become global threats. The SARS outbreak (2002/03), MERS (2012) and the Ebola virus (e.g. 20182020) epidemic drew attention years ago to the fact that the conjuncture of globalization, social inequality and the epidemic spread of a pathogen is a potentially dangerous mix. The need to permanently deal with hazards and insecurities resulting from the modernization process itself is a characteristic of modern 'risk societies' (Beck, 1992) and inherent to 'liquid' or 'reflexive' modernity (Baumann, 2000), where everything undergoes constant processes of transformation.

Discourses of danger, risk and hazards are permanently spread via the media. Nature being 'out of control' makes front-page news, and increasingly such discourse, through people's participation in social media, influences signification in the world of social media. Whilst traditional media form and disseminate representations and significations of what is and could be, an ever-growing number of media producers spread mis- and disinformation. This also holds true for maps, which are never just representations of the physical world but are always instruments of power (Pavlovskaya, 2018). GIS offers new possibilities to negotiate and shape power relations, since digital and online mapping can be used as tools for social transformation, but also to spread mis- and disinformation. Being able to distinguish between fact and fake is more and more difficult in times 'where nothing can be taken for granted, where no frame of understanding or of action can be entertained with any security, [...] in which we are conceptually challenged, and continually so' (Barnett, 2000: 257).

When anything can change from one day to the next, as during the current Covid-19 pandemic (e.g. restrictions on movement and social life), concepts of flexibility, adaptability and resilience become of key importance. Resilience especially became very popular in numerous academic disciplines and beyond academia. Runguis et al. (2018) argue that resilience and its popularity can be understood as an answer to uncertainty, crisis and reflexive modernity.

Crisis situations like the current pandemic entail numerous consequences in different societal spheres. From an educational perspective, school shutdowns are among the most obvious and most challenging, especially, as early research into the pandemic shows, for learners with limited access to technology and little parental support (Huber et al., 2020). It has also been pointed out that trainee teachers in Austria have not been familiarized with the concepts and practices of distance learning (Jekel et al., 2020). Nevertheless, lockdown led to increased use of digital devices and social media among (young) people for daily information and communication (ibid). Children and young people rely heavily on media channels like YouTube as major sources of information (Medienpädagogischer Forschungsverbund Südwest, 2020: 38ff). One effect of this development is the accelerated spread of misinformation about COVID-19.

School shutdowns and the implementation of distance learning can be seen as a particular form of crisis management that is closely linked to the Covid-19 pandemic. Together with the ever-growing importance of social media as places where feelings of insecurity and uncertainty are fuelled, the pandemic points to the need to develop new educational concepts to equip young people with the skills for informed decision making, creative problem solving, and the 
ability to shape change. Intellectual resilience is one competence that will be explored and conceptualized as being important for students (not only) in times of crisis.

\section{Intellectual Resilience - Draft of a new educational approach}

In an educational context, resilience has mostly been addressed in connection with young people who have experienced personal difficulties or trauma, who therefore need to build up skills to cope with these situations. (For an overview, see Hess 2019.) Contrary to approaches which are based on a pedagogy of vulnerability and which tend to shift responsibility from society to the individual (Pollard, 2014), our approach to resilience education is informed by critical pedagogy (Freire, [1997] 2000) and civic education (Giroux, 2011); it is also linked to the social resilience approach (Keck \& Sakdapolrak, 2013), which focuses on actors and their (cap)abilities.

Education for intellectual resilience is embedded in, and linked to, several general pedagogical concepts (and others) that have been developed within the field of geography education. So far, however, none of these approaches have been operationalized in terms of education confronting crises, or global challenges and transformations. One of these approaches is the capabilities approach (Nussbaum \& Sen, 1993; Sen, 1999; Nussbaum, 2013). Originally conceived as an alternative economic approach to human welfare, it has also been adopted by social sciences more widely and used in an educational context. The concept of geocapabilities (Lambert et al., 2015) is closely linked to the capabilities approach and focuses the contribution of geography education on a person's capabilities. The geocapabilities approach aims to help learners reach their full human potential in a highly interdependent world by using the powerful disciplinary knowledge (Young, 2008) offered by geography education.

The notion of powerful disciplinary knowledge is also represented in the development of specific key concepts (Lambert, 2013) and their implementation in school curricula. (For a discussion of this in relation to Geography and Economics education in Austria, see Jekel \& Pichler, 2017). Learning with key concepts (or conceptual thinking) can support learners in understanding complex processes, foster critical thinking, help learners to deconstruct pregiven questions or solutions, as well as enable them to actively participate in societal negotiation processes.

Intellectual resilience is closely linked to concepts from civic and citizenship education (Sander, 2010; Bennett et al., 2009). The work of Bennett et al. (2009) is an important point of reference. They stress changes in young people's civic orientation, which led to two different types of citizen identity: the 'dutiful citizen' and the 'actualizing citizen' (Bennett et al., 2009: 106). Today's younger generations mostly belong to the latter group, which is characterized by less political participation in traditional ways (e.g. voting, following issues in the news) and a focus on lifestyle politics such as political consumerism, volunteering or social activism. Other attributes of the group are a mistrust of traditional media and the widespread use of digital media for communication. Bennet et al. stress the need for interactive and project-based learning environments for citizenship education. 
Interaction and learners' agency are also central to the concepts of innovativeness or education for innovation (Golser et al., 2019; Shavinina 2013), which can also be linked to intellectual resilience. Innovativeness strives to integrate the process of innovation in learning situations. It aims to improve learners' creativity, reflexivity and innovativeness by fostering critical and constructivist thinking, but also by encouraging learners to use their capabilities to find new and creative solutions to problems which they have identified themselves.

Critical spatial learning (Gordon et al., 2016) and education for spatial citizenship (Gryl \& Jekel, 2012) are further important reference points. Gordon et al. aim to foster young learners' civic engagement through critical spatial thinking. They use processes of critical digital mapping to emphasize 'how social and spatial processes intertwine to generate societal inequalities and show how this learning informs students' social and spatial civic responses' (Gordon et al., 2016: 558). These approaches also link to critical GIS (Pavlovskaya, 2018), which strives to reveal how spatial inequalities are produced and maintained. Gryl \& Jekel (2012) add a more spatial view to citizenship education in general. Their main objective is to enable learners not simply to take part in society more actively, but to do this by critically using geoinformation and geomedia. Education for spatial citizenship and critical GIS could thus be used to bridge geoinformation and intellectual resilience.

Education for intellectual resilience can further be linked to the notion of the viral construction of space (Kanwischer \& Schlottmann, 2017). This concept can be positioned at the intersection of spatial learning or education for spatial citizenship and critical (geographic) media literacy. It focuses on the changing ascriptions of the meanings of places in social media and how these meanings can go viral by being shared. To better comprehend how spatial ascriptions may go viral, reflective approaches connected to structural media theory (Jörissen \& Marotzki, 2009) are useful, since structural media theory aims to analyse changes in our conception of ourselves and our views of the world.

Finally, we draw on concepts of critical (geographic) media literacy (Kellner \& Share, 2005, 2007; Hintermann et al., 2020). Kellner \& Share point out that critical media literacy 'involves gaining the skills and knowledge to read, interpret, and produce certain types of texts and artifacts and to gain the intellectual tools and capacities to fully participate in one's culture and society' (Kellner \& Share, 2005: 365). Transferred to the field of geography education, this means the competences to read, interpret and produce spatially and economically embedded media representations as a means of participating in society in a more informed and emancipatory way (Hintermann et al., 2020).

The concept of intellectual resilience is elaborated in the context of the school subject Geography and Economics. School geography in Austria is an interdisciplinary subject that combines geography, economics and civic education with the aim of empowering learners to actively and responsibly participate in society at local and wider levels, including the global level (BGBl. II Nr. 219/2016). Taking these aims seriously means focusing on students' own (political) agency, building on their own experiences, supporting critical and conceptual thinking, and empowering them to deal with uncertainty and contingency as basic conditions in society and preconditions to improve knowledge. Intellectual resilience, then, would comprise not only the ability to adapt to difficult circumstances but also skills to question these circumstances, to perceive supposedly 'given' situations and narratives as constructed and 
changeable, and to intervene responsibly in societal transformation processes. An intellectually resilient person can therefore be defined as someone who can make use of multiple scientific approaches and concepts in a participative, democratically informed way. Table 1 gives an overview of the (cap)abilities that students need to acquire in order to become intellectually resilient. The table also outlines pedagogical and educational approaches related to these (cap)abilities.

Table 1: (Cap)abilities fostered by intellectual resilience, and corresponding educational/pedagogical approaches

\begin{tabular}{|c|c|}
\hline (Cap)ability & Corresponding approach \\
\hline $\begin{array}{l}\text { ability to question and challenge 'crisis', } \\
\text { 'risk' and 'threat' as concepts: Who } \\
\text { defines a situation as a } \\
\text { crisis/risk/threat? When is a crisis } \\
\text { (/risk/threat) a crisis (/risk/threat)? Who } \\
\text { is affected by the crisis (/risk/threat), } \\
\text { and to what extent? }\end{array}$ & $\begin{array}{l}\text { critical (geographic) media literacy, } \\
\text { civic and citizenship education }\end{array}$ \\
\hline $\begin{array}{l}\text { ability to understand the contingent nature } \\
\text { of debates and to decode propositions as } \\
\text { context-sensitive }\end{array}$ & $\begin{array}{l}\text { critical pedagogy, critical (geographic) } \\
\text { media literacy }\end{array}$ \\
\hline $\begin{array}{l}\text { ability to deconstruct (political) crisis- } \\
\text { driven rhetoric }\end{array}$ & $\begin{array}{l}\text { critical (geographic) media literacy, } \\
\text { civic and citizenship education }\end{array}$ \\
\hline $\begin{array}{l}\text { ability to realize that crises involve } \\
\text { change, and that change and transformation } \\
\text { are constants in society }\end{array}$ & $\begin{array}{l}\text { civic and citizenship education, } \\
\text { innovativeness, education for innovation }\end{array}$ \\
\hline $\begin{array}{l}\text { ability to intervene and participate } \\
\text { responsibly in societal negotiation } \\
\text { processes }\end{array}$ & $\begin{array}{l}\text { critical pedagogy, geocapabilities, } \\
\text { civic and citizenship education }\end{array}$ \\
\hline $\begin{array}{l}\text { ability to identify (social) media as major } \\
\text { actors and players in the negotiation and } \\
\text { (re)construction of 'crises', 'risks' or } \\
\text { 'threats' }\end{array}$ & $\begin{array}{l}\text { critical (geographic) media literacy, } \\
\text { viral construction of space }\end{array}$ \\
\hline $\begin{array}{l}\text { ability to work out the spatial dimensions } \\
\text { of crises }\end{array}$ & $\begin{array}{l}\text { critical spatial learning, education for } \\
\text { spatial citizenship, critical GIS, viral } \\
\text { construction of space }\end{array}$ \\
\hline $\begin{array}{l}\text { ability to phrase questions instead of } \\
\text { accepting pre-given answers }\end{array}$ & $\begin{array}{l}\text { critical pedagogy, civic and citizenship } \\
\text { education, innovativeness, education for } \\
\text { innovation }\end{array}$ \\
\hline
\end{tabular}

The (cap)abilities specified in Table 1 are not presented in any hierarchical order: education for intellectual resilience aims to strengthen all of them. Different approaches can support the acquisition or strengthening of each individual capability. In the context of education for intellectual resilience, these approaches will further be linked to the concept of social resilience. 


\section{Connecting resilience to current educational approaches}

It has been pointed out that intellectual resilience as a new educational approach needs further in-depth conceptualization. However, in what follows, and taking the Covid-19 pandemic as an example, we will illustrate how the notion of resilience can be linked with present educational concepts in order to enhance learners' knowledge and (cap)abilities. First, we need to figure out reasons for students' feelings of insecurity or uncertainty in relation to the pandemic, not simply as a health hazard. That might be the loss of financial security when parents become unemployed; changing daily routines when distance learning replaces regular school classes; issues that might occur when learning and living routines are shifted from physical to virtual space; an overload of information spread via diverse media channels, and the closely related questions of which information is to be trusted, and what is fact and what is fake.

For the sake of exemplification, we now focus on the questions of information spread, overload and trustworthiness. The ability to deal with information spread by media is clearly connected to strategies or core concepts inherent to critical media literacy. According to Kellner \& Share (2005: 375), non-transparency is the first core concept to be applied in dealing with media products. Media products, as is widely acknowledged, do not reflect reality but are representations of reality and imply construction processes (see Luhmann, 2017). Making this process visible or transparent helps to deconstruct media messages, for instance with regard to what is conveyed by a message and what is left out. In the context of the coronavirus pandemic, one could ask: What information about Covid-19 is being transmitted? What aspects are not being focused upon, or are even missing? Such questions are valid for information based on provable facts as well as for fake news.

Another important core concept in media literacy is audience decoding (Kellner \& Share, 2005: 375). The various processes of encoding and decoding media messages never provide congruency, leading to a pluralistic interpretation of media products. In other words, it is possible to gain different information from the same media product depending on the way the audience decodes the message. Learners who are aware of the concepts of non-transparency and audience decoding might handle the steady information stream on Covid-19 more easily. It is precisely at this point that critical media literacy as an educational approach and social resilience intertwine. Social resilience as Keck \& Sakdapolrak (2013) describe it is characterized by three main capacities: coping capacities, adapting capacities and transformative capacities. Coping capacities aim to restore a status quo of wellbeing, as experienced before a threat or crisis occurred. The temporal scope is short-term, and the degree of change of social structures is rather low. Linked to critical media literacy, coping capacities would imply the ability to decode media messages in a way that increases transparency and allows for a more personal reading of the information transmitted. This might lead to a restoration of former feelings of security or certainty. On a meta-level, this restoration of wellbeing could be expressed as a new capability that aims to identify (social) media as main actors and players in the negotiation and (re)construction of 'crises', 'risk' or 'threats'.

Social resilience targets not only short-term coping capacities but also adapting and transformative capacities. Applied to the Covid-19 pandemic and the trustworthiness and spread of information, we will now briefly address the interrelation of transformative capacities 
and critical media literacy. Critical media literacy and its two core concepts of content and message and motivation (Kellner \& Share, 2005: 376-77) are strongly connected to critical thinking (Dewey, 1910), which encourages values and power relations to be questioned or contested. Both content and message and motivation serve to reflect on ideologies or bias transmitted in media products and the roles that media play in the process of negotiating power. Applying these two concepts to feelings of uncertainty or insecurity caused by the pandemic opens up new, completely different, questions: Who has the power to select the information which is transmitted and how is it selected and transmitted? What interests are pursued through the communication of certain pieces of information? What possibilities are there to foster a broader participation in the process of media production? From a social resilience perspective, these questions can be addressed within the realm of transformative capacities. In order to improve individual welfare but also to strengthen societies as such against future crises, there needs to be more participation in decision-making processes (Keck

\& Sakdapolrak, 2013: 11). It becomes clear that transformative capacities relate to the long term, having a high potential to change the structures of a social system. Applied to the Covid19 situation, linking critical media literacy and social resilience can be used to foster a new capability which aims to question and challenge 'crises', 'risk' or 'threat' as concepts: Who defines which situations as crises (/risks/threats)? When is a crisis a crisis? Who is affected by the crisis and to what extent?

In brief, education for intellectual resilience aims to enhance learners' participative skills and agency in order to empower them to participate in ongoing processes of change and transformation and to navigate through a crisis like the Covid-19 pandemic towards a state of increased wellbeing, security and certainty.

\section{Outlook}

The conceptualization of intellectual resilience as a new educational approach focuses on how geography education can promote a more comprehensive understanding of crises and the complex conjuncture of risk, uncertainty, liquid modernity and (fake) news through the use of (social) media, including geomedia. In future work, based on the principles of Participatory Action Research (Coghlan \& Brydon-Miller, 2014), the concept will be elaborated collaboratively in a workshop setting with students in higher secondary education. Strategies and methods to facilitate intellectual resilience will be explored and implemented, with the aim of developing a practical and adaptive tool kit that can readily be employed in the classroom. 


\section{References}

Barnett, R. (2000). Supercomplexity and the Curriculum. Studies in Higher Education 25(3), 255-265. DOI: $10.1080 / 713696156$.

Baumann, Z. (2000): Liquid Modernity. Cambridge: Polity Press.

Beck, U. (1992). Risk Society: Towards a New Modernity. London: Sage.

Bennett, W. L., Wells, C., \& Rank, A. (2009). Young Citizens and Civic Learning: Two Paradigms of Citizenship in the Digital Age. Citizenship Studies 13(2), 105-120. DOI: 10.1080/13621020902731116.

BGBl. II Nr. 219/2016: Änderung der Verordnung uiber die Lehrpläne der allgemeinbildenden höheren Schulen; Änderung der Bekanntmachung der Lehrpläne für den Religionsunterricht an diesen Schulen.

Coghlan, D., \& Brydon-Miller, M. (Eds.) (2014). The Sage Encyclopedia of Action Research. Los Angeles, London, New Dehli, Singapore \& Washington DC: Sage.

Dewey, J. (1910). How we think. Lexington: DC Heath.

Freire, P. (2000). Pedagogy of the Oppressed. New York: Continuum Publishing.

Giroux, H. A. (2011). On Critical Pedagogy. New York: Continuum.

Golser, K., Scharf, C., \& Jekel, T. (2019). Schüler*innen als Innovator*innen: Das Projekt Innovativitäts_Schulen (Inno_Schools). OpenSpaces 01/2019, 60-70.

Gordon, E., Elwood, S., \& Mitchell, K. (2016). Critical spatial learning: participatory mapping, spatial histories, and youth civic engagement. Children's Geographies 14(5), 558-572. DOI: 10.1080/14733285.2015.1136736.

Gryl, I., \& Jekel. T. (2012). Re-centering GI in secondary education. Towards a spatial citizenship approach. Cartographica 47(1): 18-28. DOI: 10.3138/carto.47.1.18.

Hess, J. (2019). Moving beyond resilience education: musical counterstorytelling. Music Edcuation Research 21(5), 488-502. DOI: 10.1080/14613808.2019.1647153.

Hintermann, C., Bergmeister, F. M., \& Kessel, V. A. (2020). Critical Geographic Media Literacy in Geography Education: Findings from the MiDENTITY Project in Austria. Journal of Geography 119(4): 115-126. DOI: 10.1080/00221341.2020.1761430.

Huber, S. G., Günther, P.S., Schneider, N., Helm, C., Schwander, M., Schneider, J. A., \& Pruitt, J. (2020). COVID-19 und aktuelle Herausforderungen in Schule und Bildung: Erste Befunde des Schul-Barometers in Deutschland, Österreich und der Schweiz. Münster/New York: Waxmann.

Jekel, T., Oberrauch, A. \& Breitfuss-Horner, C. (2020). „Ich habe unbekannte Seiten und Talente meiner Schuler/innen entdeckt": Eine Delphi-Studie zum Ist-Stand und Entwicklungsstrategien zur fachspezifischen Fernlehre an österreichischen Sekundarschulen. GW-Unterricht 158, 57-67. DOI: $10.1553 / \mathrm{gw}-$ unterricht158s57.

Jekel, T., \& Pichler, H. (2017). Vom GW-Unterrichten zum Unterrichten mit geographischen und ökonomischen Konzepten: Zu den neuen Basiskonzepten im österreichischen GW-Lehrplan AHS Sek II., GW-Unterricht 147, 5- 15. DOI: 10.1553/gw-unterricht147s5.

Jörissen, B., \& Marotzki, W. (2009). Medienbildung - eine Einführung: Theorie - Methoden Analysen. Bad Heilbrunn: Klinkhardt.

Kanwischer, D., \& Schlottmann, A. (2017). Virale Raumkonstruktionen: Soziale Medien und Mündigkeit im Kontext gesellschaftswissenschaftlicher Medienbildung. ZDG 8(2), 60-78.

Keck, M., \& Sakdapolrak, P. (2013). What is social resilience?: Lessons learned and ways forward. Erdkunde 67(1), 5-19. DOI: 10.3112/erdkunde.2013.01.02.

Kellner, D., \& Share, J. (2005). Toward critical media literacy: Core concepts, debates, organizations, and policy. Discourse: Studies in the Cultural Politics of Education 26(3), 369-386. DOI: 10.1080/01596300500200169. 
Kellner, D., \& Share, J. (2007). Critical media literacy is not an option. Learn Inquiry 1(1), 59-69. DOI: 10.1007/s11519-007-0004-2.

Lambert, D. (2013). Geographical concepts. In M. Rolfes and A. Uhlenwinkel (Eds.) Metzler Handbuch 2.0 Geographieunterricht: Ein Leitfaden für Praxis und Ausbildung. Braunschweig: Westermann.

Lambert, D., Solem, M., \& Tani. S. (2015). Achieving Human Potential Through Geography Education: A Capabilities Approach to Curriculum Making in Schools. Annals of the Association of American Geographers 105(4), 723-735. DOI: 10.1080/00045608.2015.1022128.

Luhmann, N. (2017). Die Realität der Massenmedien (5th edition). Wiesbaden: Springer.

Medienpägagogischer Forschungsverbund Südwest. (2020). JIM-Studie 2019: Jugend, Information, Medien: Basisuntersuchung zum Medienumgang 12- bis 19-Jähriger. Retrieved from https://www.mpfs.de/fileadmin/files/Studien/JIM/2019/JIM_2019.pdf.

Nussbaum, M. (2013). Creating capabilities: The human development approach. Cambridge, MA: Routledge. OECD. 2020. Economic Outlook, Interim Report September 2020. Paris: OECD Publishing. DOI: $10.1787 / 34 \mathrm{ffc} 900-\mathrm{en}$.

Nussbaum, M., \& Sen, A. (1993). The quality of life. Oxford, UK: Routledge.

Pavlovskaya, M. (2018). Critical GIS as a tool for social transformation. The Canadian Geographer 62(1), 40-54. DOI: 10.1111/cag.12438.

Pollard, T. J. (2014). Education, the Politics of Resilience, and the War on Youth: A Conversation with Brad Evans. Review of Education, Pedagogy, and Cultural Studies 36(3), 193-213. DOI: 10.1080/10714413.2014.917902.

Runguis, C., Schneider, E., \& Weller, C. (2018). Resilienz - Macht - Hoffnung: Der Resilienzbegriff als diskursive Verarbeitung einer verunsichernden Moderne. In M. Karidi, M. Schneider, \& R. Gutwald (Eds.), Resilienz: Interdisziplinäre Perspektiven zu Wandel und Transformation. Wiesbaden: Springer.

Sander, W. (2010). Wissen im kompetenzorientierten Unterricht - Konzepte, Basiskonzepte, Kontroversen in den gesellschaftswissenschaftlichen Fächern. ZDG 1(1), 42-66.

Sen, A. (1999). Development as freedom. New Delhi: Routledge.

Shavinina, L. (2013). The Routledge international Handbook of Innovation Education. London \& New York: Routledge.

UN Department of Economic and Social Affairs. (2020). Everyone Included: Social Impact of COVID-19. Retrieved from https://www.un.org/development/desa/dspd/everyone-includedcovid-19.html

Young, M. (2008). From constructivism to realism in the sociology of the curriculum. Review of research in education 32, 1-28. 